\title{
Educational Values Included in Story Collections for Fourth and Fifth Grade Students in Jordan
}

\author{
Mohammad N. M. Ayasrah", Shima M. S. Yahyaa ${ }^{1}$, Omar M. K. Al-Mahasneh,", \\ ${ }^{1}$ Department of Educational Sciences, Faculty of Irbed University College, AL-Balqa Applied University, Jordan \\ ${ }^{2}$ Department of Basic and Applied Science, Faculty of Shobak University College, AL-Balqa Applied University, Jordan
}

Received July 19, 2020; Revised September 30, 2020; Accepted October 19, 2020

\begin{abstract}
Cite This Paper in the following Citation Styles
(a): [1] Mohammad. N.M. Ayasrah, Shima. M.S. Yahyaa, Omar. M.K. Al-Mahasneh, "Educational Values Included in Story Collections for Fourth and Fifth Grade Students in Jordan," Universal Journal of Educational Research, Vol. 8, No. 11B, pp. 5859 - 5868, 2020. DOI: 10.13189/ujer.2020.082219.
\end{abstract}

(b): Mohammad. N.M. Ayasrah, Shima. M.S. Yahyaa, Omar. M.K. Al-Mahasneh (2020). Educational Values Included in Story Collections for Fourth and Fifth Grade Students in Jordan. Universal Journal of Educational Research, 8(11B), 5859 - 5868. DOI: 10.13189/ujer.2020.082219.

Copyright $\odot 2020$ by authors, all rights reserved. Authors agree that this article remains permanently open access under the terms of the Creative Commons Attribution License 4.0 International License

\begin{abstract}
The study sought to identify the educational values (Cognitive, health, social, personal, national) included in story collection for fourth and fifth grade students in Jordan and their indicators. Another objective was to define the percentage of including these values based on school semester and grade level. An instrument was developed to answer the questions of the study. The sample of the study was all the population which was the story collection for fourth and fifth grade students starting from the school year 2017. These were (4) story collection distributing on (4) group for each grade level. The study findings indicated that educational values were all included in the story collection for both grade levels. Social values ranked first, with (35.5\%) for fourth grade, and (40\%) for fifth grade, while health values ranked last with $(3 \%)$ for fourth grade, and (11.4\%) for fifth grade. The study suggested some recommendations and the most important is to pay more attention to health values as they are a reflection of student's awareness of the importance of health practices and their positive effect on their personal life and the surrounding environment.
\end{abstract}

Keywords Educational Values, Story Collection, Basic Education

\section{Introduction}

Paying attention to childhood reflects the desire to develop both the present and the future when knowing that societies wishing to achieve higher levels of development in all fields concentrate on the first five years of the individual's life which is a focal point for future growth. This critical period in children life has been one of the main concerns of educational institutions such as kindergarten and basic schools. These play a vital role in forming children personalities and developing their abilities and skills (Al-Zreqat \& Naser, 2005; Al-Nashef, 2017).

The total educational system is highly related with promoting student's values. If the educational system does not focus on developing positive values among student's populations, the whole educational process is soulless. To achieve advancement and developments in this era, the role of education for values should be the main focus if such an objective is to be accomplished. The early years in student life are curtail since what is learned and absorbed will define student's future life course. The concerns about society values are not a new topic when knowing that policy makers and teachers have only been striving to create a qualitative education able to promote values among students in light of society aspirations and expectations (Gulati\& Pant, 2020).

Basic education is the key pillar for creating an individual attached to its nation and home land. It installs values, holds students in acquiring concepts while developing abilities, attitude and interest making an individual active in his society. The educational philosophy for any educational system is to make all learning and 
teaching processes active for achieving higher standards of values (Al-Yamany, 2015). For example, the educational philosophy of Jordan stems from the Jordanian constitution, the concepts of Islamic and Arab civilization and the Arab great revolve principles (Ministry of Education, 2003). As such, the curricula elements are all derived from the society philosophy that is a measure for its members' behaviors and action. In this sense, children are the essence of the teaching learning process by focusing on his cognitive, social, personal, national and health values (Al-Jalad, 2013).

Indeed, values are all rules and standards emerging from an agreement between a group of individuals while representing indicators employed for judging the moral and material actions and practices shown by an individual belonging to such group. These values have a great influence in this group as they are necessary for living in a specific group while being abiding for all members. Any violation of such values is considered a form of opposition for the group goals and its higher ideals (Tan, 2008; Toots, 2003).

Children acquire their values by the various different experiences they encounter within their families in their early years. A few years later, this surrounding becomes larger and includes the societies. The school represents the first society for the student as it is a social and educational institution aiming to provide all experiences to present a plan preparation for individuals in away informing with the values prevailing the society. This quest achieved by the school curricula is embodied in text books. Focusing on creating balance between cognition skills and emotion for students; making them active citizens in their society (Qatamy, 2016).

This strategic goal can only be reached if children are addressed on both cognitive and emotional levels by using simple and interesting methods making the different values presented in the school curricula one form of the daily practices students show as a reflection of their desire to be responsible of their nations' development. please rephrase this sentence Knowing that reading is a mental activity targeting that the reader understands the reading text easily and smoothly and its away to acquire knowledge and values by connecting the written symbols with their semantics (Al-Baga, 2017), the Jordanian Ministry of Education was very keen to support basic stage grades students learning of basic skills, especially reading. To achieve this, it works in developing story collection, supporting the reading text provided to fourth and fifth basic grades starting from 2017. Since storytelling is one of the most educational teaching methods that can be employed to make students acquire values as they have created influence on both the reader and the listener; it is able to make the abstract meaning and concepts more tangible and easier to perceive and understand (Al-Hareary, 2015; Chrisite,Jacob\&Lory,2010), teachers in the Jordanian schools are called to discuss students with the learning content included in stories and all the values and attitudes they address so as they can acquire them smoothly (Ministry of Education, 2003).

Storytelling is one instructional strategy that has gained much attention by teachers in the last few years for many reasons. It provides opportunities for interaction and knowledge instruction at the same time. Confirming this, Ellis and Brewster (1991) indicated that listening to stories develops students' listening skills among children in addition to making them more attentive; and this allows to understanding the general idea of the story and connecting it with his personal experience. In this respect, it can be also said that storytelling is a valuable constructional strategy to be implemented in all topics at classes as it integrates content themes with language development levels of students. It is a strategy suitable for early age students since it makes their learning experiences interesting and purposeful.

For example, Ellis and Brewster (1991) stressed the fact that stories are a useful instrument for connecting imagination and creativity with child daily life. It provides a way to enable children to better understand their daily life while working on creating strong relations between children's home and school environment during the development of storytelling project designed Ellis and Brewster using storytelling enables students to relate ideal concepts presented in stories with their personal experiences. Additionally, it enhances the opportunities for developing language skills (listening, reading, comprehension and vocabulary) as it stimulates and encourages children to feel safe in providing their ideas in away allowing them to ask questions about the way their moral lives is developed relating to ideal or different behaviors and to compare them with the one's presented in stories (Combariza, Chapetón and Rincón, 2013; Mahasneh, 2020a; Mahasneh, 2020b; Almseidein and Mahasneh, 2020; Tawarah, and Mahasneh, 2020; Al-Mahasneh, Ayasrah, Yahyaa, Al-Kriemeen and Al-Swalha, 2020; Mahasneh, 2020c).

\section{Materials and Methods}

\subsection{Problem of the Study}

Educational stories for children one of the important means facilitating children's acquisition of knowledge, values, traditions and attitudes an easy smooth process (Al-Deeb, 2006). Educational stories after the age of six should focus on cognitive concepts promoting thinking and encouraging enquiry. They also should work on installing the love of the homeland and be an active citizen while acknowledging that being a member of the Arab nation is very important while maintaining good traditions in addition to being attention to practicing healthy habits (Al-Anany, 2017). 
Because this contemporary world is witnessing drastic and continuous cultural changes that negatively affect values, attitude and behavior; thus, leading to the development of various social and psychological problems having negative impact on individuals believes and actions, there should be a special consideration to what is presented to children in schools in the form of learning content that can contribute to their abilities to think and solve problems in within a reference of values making them able to distinguish between right and wrong (Souada\& Ibrahim, 2011).

\subsection{Questions of the Study}

Since childhood is a turning point in life as child personality (skills, cognition values) are formulated during this period; and when considering the positive effect and significance effect of educational stories in preparing a balanced and functional personality for students; and when realizing that stories collections provided for fourth and fifth grade students in Jordan are a qualitative addition for textbooks in these grades, there is a need to define the cognitive, health, social, and national values included in them. For this reason, the current study attempted to answer these questions:

1. What are the cognitive, health, social, and national values included in story collections provided for fourth and fifth grade students in Kingdom of Jordan and what are their indicators?

2. Are there differences in the inclusion level of cognitive, health, social, and national values included in story collections provided for fourth and fifth grade students in Kingdom of Jordan due to grade level?

\subsection{Significance of the Study}

The significance of this study stems from the role played by values in individuals' life and their direct effect on principles, standards and concepts adopted by him when making judgment about the actions in the surrounding environment and in organizing and directing individual behavior. Furthermore, the significance of this study is echoed by the vital role of childhood period, a period that all community institutions take a special consideration when realizing its importance for the following periods. As such, learning experiences at this delicate and sensitive period should be meaningful and concentrated.

Evaluation is a process where information is collected to measure the effectiveness of the curricula, its trustworthiness, and visibility in reflecting the basic tenens of the education philosophy, to make use of its strength while overcoming its weakness. The introduction of education stories in the Jordanian schools started in 2006 when the project of the "My Arab Library" was presented based on translated stories that were not positively received by student parents as it was expected. Additionally, these stories did not concentrate on Jordanian heritage and were under expectations (Al-Zboun\& Al-Daqas, 2009). Based on this, this study is one of the pioneering studies aiming to examine all stories collections provided to fourth and fifth grade students in Jordanian schools and analyzing them. As such, this study may pave the way for future researchers interested in examining these collections. Finally, it is hoped that the results of this study may contribute in developing these stories collections.

\subsection{Operational Definitions}

Educational Values: A set of principles, standards and concepts an individual adopts for judging actions in the society he belongs to according to the value system and the prevailing moral values. They are used to organize and direct individuals' behaviors in this society (Al-Khawaldeh, 2011). This study included a group of cognitive, health, social, personal and national indicators.

Story Collections: These include all stories provided to fourth and fifth basic grade students at Jordanian schools they totaled (8) collections distributing at fourth and fifth grades (4) for each grade. Two collections are taught in the first semester and two in the second

\subsection{Previous Studies}

Several studies have examined educational values in school textbooks and education stories. Researchers reviewed a group of related literature and previous studies which included university thesis and dissertations, Arab and foreign journal, the internet, and EPSCO HOST ERIC. Some of these studies were selected based on their relatedness to the variables examined in them and the variable investigated in this study. These studies are chronologically presented.

For example, Isbell, Sobol \& Lindauer (2004) sought in their study to define how story narration and story reading can affect language development and reading comprehension among toddlers. In this study, two groups of toddlers listened to the same stories (24 stories) as group A were administrated to stories using narration, while group B listened to the same stories read from a book. A language development achievement test was administrated before and after listening to stories by rereading a narrated story and creating a story using comics without words. The language samples were copied and analyzed using language difficulty measures and story comprehension measures. It was found in this study that both story narration and story reading lead to positive outcomes in verbal language. The study showed that toddlers hearing the narrative stories reported higher level of reading comprehension when the story was re-narrated by them.

Another study by Ebwany (2008) investigated the educational contents included at Wesam and Hatem Jordanian magazines. Another objective was to define the 
influence of these contents on children's behaviors from the point of view of experts in child literature in Jordan. The study found that social values ranked first at Wisam magazine, while cognitive values ranked first at Hatem magazine.

Mahmoud (2009) investigated the success of the first three basic grades female teachers in Jordan as part of "My Arab Library" project in students' encouragement to read and learn. The study concluded that there were statistically significant differences between the pretest and posttest, in favor of the posttest which indicates that female teachers were successful in achieving the purpose of "My Arab Library" project.

Al-Zboun and Al-Daqas (2009) surveyed the perceptions of school principals, teachers and from first to sixth grades students and their parents about "My Arab Library" project provided by Jordanian Ministry of Education. The most important result reported in this study was the presentation of books within "My Arab Library" project does not reach the optimal levels. It was also found that parents' interactions with the project were low. The study recommended to add some books related to the Jordanian heritage in this project.

Hussein (2011) sought to define the educational values contained in "My Arab Library" project stories and their reflections on children's behavior in Jordan from teachers' perceptions. The study concluded that the cognitive values domain ranked first in the educational values contained, while the sport values domain ranked last. There was a balance in the distribution of values between the school stages. The study also showed that the educational values contained in storied reflection on children behaviors were high from teachers' perceptions. The study recommended focusing on all values.

Rahim and Rahiem (2012) identified the role of teachers in employing educational stories for teaching educational values for children in Indonesia. The study indicated that there is a lack in preparing teachers employing educational stories for teaching values. Furthermore, teachers' roles in concentrating in educational values included in stories is very significant so as students can acquire them. The study suggested that there is a need to identify teachers believes about the importance of teaching educational values for children.

Chua (2017) presented a filed demonstration of social studies secondary teachers in Singapore employment for stories to achieve various educational purposes. It was noticed in the study that the use of stories achieved different objectives such as teaching ethics, encouraging empathy and cultural understanding, motivating students' engagement and helping them in acquiring higher order thinking skills such as assessing the authenticity of resources. If used effectively, stories may achieve various objectives such as installing the values of active citizenship among students, additionally, skills targeted by students at all ages maybe promoted using stories. There were several suggestions about how teachers can integrate story narration in their classes. Despite the fact that the four storied examined in this study were from secondary school level, the ideas and suggestions presented in this study may be applied in the different school level grades.

Reviewing previous studies, it can be noticed that the majority of them addressed the employment of "My Arab Library" project which is a grant from the US Government to the Hashemite Kingdom of Jordan and other Arab countries. In 2006, one of the American firms (Scholastic) donated a set of translated books to encourage students on reading as the Jordanian curriculum lacks education stories. These stories were combined with the Jordanian Curricula in 2015. For this reason, this study came to identify the educational values included in story collection provided for fourth and fifth basic grade students at the Hashemite Kingdom of Jordan.

\subsection{Methodology}

Researchers employed descriptive analytical design which detects the status of the studied phenomenon as it is. The stories collections of the study were analyzed to detect the educational values included in them, then classified based on the indicators of each value specified in the study.

\subsection{Population and Sample of the Study}

The study population included the story collections for the fourth and fifth grades starting from the school year 2017. These grades were selected in aim to complete the previous work of Ayasrah and his colleagues (2017) about the values included in the story collections for the first three grades.

Table 1. Story Collections for Fourth and Fifth Grades Distributed into the First and Second Semester

\begin{tabular}{|c|c|c|}
\hline Grade & $\begin{array}{l}\text { Stories Collections / First } \\
\text { Semester }\end{array}$ & $\begin{array}{c}\text { Stories Collections / } \\
\text { Second Semester }\end{array}$ \\
\hline $\begin{array}{l}\text { Fourth } \\
\text { Grade }\end{array}$ & $\begin{array}{l}\text { First Collection: Perfect } \\
\text { class, who plays with the } \\
\text { elephant, The little painter } \\
\text { Second Collection: } \\
\text { Mamoun and soap bubbles, } \\
\text { Cooperating friends }\end{array}$ & $\begin{array}{l}\text { First Collection: A letter } \\
\text { to the birds, } \\
\text { grandchildren gift, Forest } \\
\text { ranger } \\
\text { Second Collection: Good } \\
\text { intentions, The benefit of } \\
\text { work }\end{array}$ \\
\hline $\begin{array}{l}\text { Fifth } \\
\text { Grade }\end{array}$ & $\begin{array}{l}\text { First Collection: Earth is } \\
\text { giving, friendship is a smile } \\
\text { and hope } \\
\text { Second Collection: } \\
\text { Beautiful garden, Beautiful } \\
\text { response }\end{array}$ & $\begin{array}{c}\text { First Collection: } \\
\text { Azzawheat stalk, The joy } \\
\text { of success, Affection and } \\
\text { tenderness } \\
\text { Second Collection: } \\
\text { Homeland love, The fruit } \\
\text { order }\end{array}$ \\
\hline
\end{tabular}

\subsection{Instrument of the Study}

After reviewing the previous studies related to the study subject (ex. Ebwany, 2008; Mahmoud, 2009; Al-Zboun\& Al-Daqas, 2009; Hussein, 2011; Rahim \&Rahiem, 2012). 
Then, a list of the indicators of cognitive, health, social, personal and national values was prepared in its preliminary format (Appendix 1). Its validity and reliability were investigated before applying.

\subsection{Analyzing Unit}

Meaningful interconnected paragraph was adopted as the analysis unit for the study instrument.

\subsection{Validity and Reliability}

The instrument of the study was verified by distributing it on (7) experts specializing in curricula, instructional methods, and Arabic Language, as they were asked to give their opinions on the instrument. Based on the experts' agreements, the final format of the instrument included indicators of cognitive, health, social, personal and national values. The paragraph was defined as a unit of analysis for the study instrument, as every single paragraph in the story represented a specific value. After the values were collected, they were classified to the indicator to which they belong, the frequencies and percentages of each value were collected.

\subsection{Reliability of the Content Analysis Framework}

Researchers investigated reliability by using content analysis through a time interval of two weeks. Agreement coefficient was calculated by using Hotelling Trace.

\section{Reliability Coefficient $=$ \\ $\frac{\text { numbers of points of agreement }}{\text { numbers of points of agreement }+ \text { numbers of ponts of disagreement }}$ $\times 100 \%$}

The agreement coefficient reached $(89 \%)$, which is a percentage indicating the reliability of the analysis process. Two researchers analyzed the content individually. Then, with using the same equation, the reliability coefficient was (91\%), a percentage indicating the reliability of the analysis process.

\section{Results}

Results of the First Question: "What are the cognitive, health, social, and national values included in story collections provided for fourth and fifth grade students in Kingdom of Jordan and what are their indicators?"

To answer this question, researchers analyzed the study story collections by using the study instrument, and the indicators of each value were identified, as shown in Table (2). 
Table 2. Cognitive, Health, Social, Personal, and National Values Included in Story Collection for Fourth and Fifth Grade Students in Kingdom of Jordan and its Indicators

\begin{tabular}{|c|c|c|c|c|}
\hline Grade & Story Collection & Story Title & Values Type & Indicators \\
\hline \multirow{10}{*}{$\begin{array}{l}\text { Fourth } \\
\text { Grade }\end{array}$} & \multirow{3}{*}{$\begin{array}{l}\text { First Collection / } \\
\text { First Semester }\end{array}$} & Perfect class & $\begin{array}{l}\text { Social } \\
\text { Health } \\
\text { National }\end{array}$ & $\begin{array}{ll} & \text { Stressing the importance of collaboration } \\
\text { - } & \text { Encouraging personal hygiene } \\
\text { - } & \text { Promoting patriotism } \\
\end{array}$ \\
\hline & & $\begin{array}{l}\text { Who plays with } \\
\text { the elephant?! }\end{array}$ & $\begin{array}{c}\text { Social } \\
\text { Cognitive }\end{array}$ & $\begin{array}{ll} & \text { Caring for others feelings } \\
\text { Encouraging problem understanding and providing scientific } \\
\text { solutions }\end{array}$ \\
\hline & & The little painter & Personal & $\begin{array}{ll}- & \text { Persistence } \\
\text { - } & \text { Self-Reliance }\end{array}$ \\
\hline & \multirow[t]{2}{*}{$\begin{array}{l}\text { Second } \\
\text { Collection / First } \\
\text { Semester }\end{array}$} & $\begin{array}{l}\text { Mamoun and } \\
\text { the soap bubbles }\end{array}$ & $\begin{array}{l}\text { Cognitive } \\
\text { Social }\end{array}$ & $\begin{array}{ll}- & \text { Developing Thinking } \\
\text { Encouraging problem understanding and providing scientific } \\
\text { solutions } \\
\text { - } \quad \text { Stressing the importance of collaboration } \\
\text { Ensuring loving other members of the society }\end{array}$ \\
\hline & & $\begin{array}{c}\text { Cooperating } \\
\text { friends }\end{array}$ & Social & $\begin{array}{ll} & \text { Importance of respecting others } \\
\text { - } & \text { Stressing the importance of collaboration }\end{array}$ \\
\hline & \multirow{3}{*}{$\begin{array}{l}\text { First Collection / } \\
\text { Second Semester }\end{array}$} & $\begin{array}{l}\text { A letter to the } \\
\text { birds }\end{array}$ & $\begin{array}{l}\text { Cognitive } \\
\text { Social } \\
\text { Personal }\end{array}$ & $\begin{array}{ll} & \text { Developing Thinking } \\
\text { Encouraging problem understanding and providing scientific } \\
\text { solutions } \\
\text { - } \quad \text { Caring for others feelings } \\
\text { Self-Reliance }\end{array}$ \\
\hline & & $\begin{array}{l}\text { grandchildren } \\
\text { gift }\end{array}$ & $\begin{array}{l}\text { Personal } \\
\text { Cognitive }\end{array}$ & $\begin{array}{ll} & \text { Seriousness } \\
& \text { Persistence } \\
\text { Developing Thinking } \\
\text { Encouraging problem understanding and providing scientific } \\
\text { solutions }\end{array}$ \\
\hline & & Forest Ranger & $\begin{array}{l}\text { Personal } \\
\text { National }\end{array}$ & $\begin{array}{ll} & \text { Seriousness } \\
& \text { Self-Reliance } \\
& \text { Promoting patriotism } \\
\end{array}$ \\
\hline & \multirow{2}{*}{$\begin{array}{c}\text { Second } \\
\text { Collection / } \\
\text { Second Semester }\end{array}$} & Good intentions & $\begin{array}{l}\text { Cognitive } \\
\text { Social }\end{array}$ & $\begin{array}{ll} & \text { Developing Thinking } \\
\text { - } & \text { Stressing the importance of collaboration } \\
& \text { Importance of respecting others } \\
\end{array}$ \\
\hline & & $\begin{array}{l}\text { The benefits of } \\
\text { work }\end{array}$ & $\begin{array}{l}\text { Cognitive } \\
\text { Social } \\
\text { Personal }\end{array}$ & $\begin{array}{ll} & \text { Developing Thinking } \\
- & \text { Stressing the importance of collaboration } \\
\text { - } & \text { Importance of respecting others } \\
& \text { Persistence }\end{array}$ \\
\hline \multirow{9}{*}{$\begin{array}{l}\text { Fifth } \\
\text { Grade }\end{array}$} & \multirow{3}{*}{$\begin{array}{l}\text { First Collection / } \\
\text { First Semester }\end{array}$} & Earth is giving & $\begin{array}{l}\text { Social } \\
\text { Personal } \\
\text { National }\end{array}$ & $\begin{array}{ll}\text { - } & \text { Stressing the importance of collaboration } \\
\text { - } & \text { Persistence } \\
\text { - } & \text { Promoting patriotism } \\
& \text { Saving gardens of homeland properties and wealth }\end{array}$ \\
\hline & & $\begin{array}{l}\text { friendship is a } \\
\text { smile and hope }\end{array}$ & $\begin{array}{l}\text { Cognitive } \\
\text { Social } \\
\text { Personal }\end{array}$ & $\begin{array}{ll} & \text { Developing Thinking } \\
\text { - } & \text { Ensuring loving other members of the society } \\
\text { - } & \text { Importance of respecting others } \\
\text { - } & \text { Discussion for others feelings } \\
\end{array}$ \\
\hline & & $\begin{array}{l}\text { Health is a } \\
\text { crown }\end{array}$ & $\begin{array}{l}\text { Cognitive } \\
\text { Health }\end{array}$ & $\begin{array}{ll} & \text { Emphasizing the importance of science } \\
& \text { Emphasizing the importance of sport } \\
& \text { Encouraging personal hygiene }\end{array}$ \\
\hline & $\begin{array}{l}\text { Second } \\
\text { Collection / First } \\
\text { Semester }\end{array}$ & $\begin{array}{l}\text { Beautiful } \\
\text { response }\end{array}$ & $\begin{array}{l}\text { National } \\
\text { Social } \\
\text { Health }\end{array}$ & $\begin{array}{ll} & \text { Promoting patriotism } \\
- & \text { Saving gardens of homeland properties and wealth } \\
\text { - } & \text { Stressing the importance of collaboration } \\
& \text { Encouraging personal hygiene }\end{array}$ \\
\hline & \multirow{3}{*}{$\begin{array}{l}\text { First Collection / } \\
\text { Second Semester }\end{array}$} & Azzawheat stalk & $\begin{array}{l}\text { Personal } \\
\text { Social } \\
\text { National } \\
\text { Health }\end{array}$ & $\begin{array}{ll} & \text { Time respect } \\
\text { - } & \text { Stressing the importance of collaboration } \\
\text { - } & \text { Saving gardens of homeland properties and wealth } \\
\end{array}$ \\
\hline & & $\begin{array}{l}\text { The joy of } \\
\text { success }\end{array}$ & $\begin{array}{l}\text { Social } \\
\text { Personal } \\
\text { Cognitive }\end{array}$ & $\begin{array}{ll} & \text { Fulfilling responsibilities } \\
\text { - } & \text { Caring for others feelings } \\
\text { - } & \text { Seriousness } \\
& \text { Persistence } \\
& \text { Developing Thinking }\end{array}$ \\
\hline & & $\begin{array}{l}\text { Affection and } \\
\text { tenderness }\end{array}$ & $\begin{array}{l}\text { Social } \\
\text { National }\end{array}$ & $\begin{array}{ll} & \text { Ensuring loving other members of the society } \\
\text { - } & \text { Importance of respecting others } \\
\text { - } & \text { Saring for others feelings } \\
\end{array}$ \\
\hline & \multirow[t]{2}{*}{$\begin{array}{c}\text { Second } \\
\text { Collection / } \\
\text { Second Semester }\end{array}$} & Homeland love & $\begin{array}{l}\text { National } \\
\text { Social }\end{array}$ & $\begin{array}{ll} & \text { Promoting good habits } \\
- & \text { Promoting patriotism } \\
& \text { Saving gardens of homeland properties and wealth } \\
& \text { Discussion } \\
& \text { Caring for others feelings } \\
\end{array}$ \\
\hline & & The fruit order & $\begin{array}{l}\text { Cognitive } \\
\text { Health }\end{array}$ & $\begin{array}{ll}- & \text { Promoting curiosity } \\
- & \text { Encouraging personal hygiene }\end{array}$ \\
\hline
\end{tabular}


Results of the Second Question: "Are there differences in the inclusion level of cognitive, health, social, and national values included in story collections provided for fourth and fifth grade students in Kingdom of Jordan due to grade level?"

To answer this questions frequencies and percentages of the educational values included in story collection for fourth and fifth grade students in Kingdom of Jordan were calculated, as shown in Table (3).

Table 3. Frequencies and percentages of the educational values included in story collection for fourth and fifth grade students

\begin{tabular}{|c|c|c|c|}
\hline Grade & Domains & Frequencies & Percentages \\
\hline \multirow{4}{*}{$\begin{array}{c}\text { Fourth } \\
\text { Grade }\end{array}$} & Cognitive & 9 & $29.1 \%$ \\
\cline { 2 - 4 } & Health & 1 & $3 \%$ \\
\cline { 2 - 4 } & Social & 11 & $35.5 \%$ \\
\cline { 2 - 4 } & Personal & 7 & $22.6 \%$ \\
\cline { 2 - 4 } & National & 3 & $9.6 \%$ \\
\hline \multirow{4}{*}{$\begin{array}{c}\text { Fifth } \\
\text { Grade }\end{array}$} & Total & 31 & $100 \%$ \\
\cline { 2 - 4 } & Cognitive & 5 & $14.3 \%$ \\
\cline { 2 - 4 } & Health & 4 & $11.4 \%$ \\
\cline { 2 - 4 } & Social & 14 & $40 \%$ \\
\cline { 2 - 4 } & Personal & 4 & $11.4 \%$ \\
\hline \multirow{3}{*}{} & National & 8 & $23 \%$ \\
\hline & Total & 35 & $100 \%$ \\
\hline
\end{tabular}

Table (3) shows that (31) educational values have been included in stories collections of the fourth grade, while (35) educational values have been included in stories collections of the fifth grade.

\section{Discussion}

1. It can be noted from reviewing table (2) that all types of values have been included, which shows that stories collections developers are interested in including all types of educational values for fourth and fifth grades students. Also, it can be noted that the story within the stories collection often included more than one educational value. It can be attributed to the fact that the educational curriculum should aim to provide students with educational experiences that contribute in developing the different aspects of their personality, including the different values (Al-Hashmy \& Atyah, 2011).

2. It can be noted that there is diversity in the indicators of the educational values whether in the same story, in the same collection, the same semester or in the same class. This can be attributed to the fact that the need to deepen the educational values in basic stage students, needs to emphasize and repeat them in different ways and forms that reinforce them in students, which makes it part of their cognitive and emotional structure (Al-Khataybeh, 2011). This is consistent with the educational improvements that the Jordanian Ministry of Educations aims to, which is based on three things: Novelty, reformation, and change, together they achieve the desired educational development. This requires giving up traditional methods in inculcating educational values among students, and searching for new ones that keep pace with the development around us. There is no doubt that selecting meaningful educational stories drawn from students' environment comes is an important thing, which is an appreciated effort by the Ministry of education since it did not resort to translated stories, which cannot address the Jordanian culture.

3. It can be noted by reviewing table (3) that (31) educational values were included in the stories' collections of the fourth grade, while (35) educational values have been included in stories collections of the fifth grade. This can be attributed to the consideration of reading ability of the students in both grades, as some fifth-grade stories were longer compared to fourth grade stories.

4. Table (3) shows that social values were most commonly included in the fourth-grade stories collections, with a percent of $(35.5 \%)$, followed by cognitive values with a percent of $(29.1 \%)$, which is the same as the fifth grade, as the social values percent was $(40 \%)$, followed by national values with a percent of $(23 \%)$. This can be attributed to the fact that humans are civilians by nature (IbnKhaldun, 2007). Individual cannot live by himself, for this reason the basic stage is considered a field that provides students with different social experiences such as collaboration and caring for others feelings, which are indicators that have been included in the results of the first question. This may help them maintain their balance and social relationships that face a financial challenge in the era in which we live (Shrief, 2017). Concentrating on national values has an important role in the Jordanian Hashemite Kingdom development, through achieving the new generations belonging to their homeland and preserving its properties and wealth, which have an important role in eliminating societal violence phenomenon that has become an essential problem for all community institutions.

5. By reviewing table (3) it can be noted that the lowest percent in the stories collections for the fourth grade was for health values with a percent of $(3 \%)$, while it was for health and personal values with a percent of $(10.6 \%)$ for both for the fifth grade. For this reason, the researchers stress the need to concentrate on these values to develop students in all domains, as health values are closely related to science, it is imperative to focus on them to in aim to provide students with knowledge, by stressing on the importance of science 
and encouraging curiosity and thinking in order to understand problems in scientific ways (Al-Khawaldeh, 2011).

6. The result related to the values included in the fifth grade (Cognitive values) is consistent with the results of Ebwany (2008) and Hussein (2010) studies, which showed that cognitive values is the most included value in the stories.

\section{Conclusions}

Teachers use stories for different reasons, as it can be used to transform knowledge into understanding as it seems that many teachers use it as a means of explanation and communicating with students. Stories also have an effective role in developing lots of the educational, social, national and cognitive values among students. In her article, Sim (2004) pointed to a helpful advice stating that is practicing is the key for a confident and effective storyteller. Furthermore, by practicing the skill of storytelling the stories are revised and collected for various occasions. Thus, teachers should not be afraid of telling stories in classes, as they may do a lot when they seize the coming opportunities or prepare well for classrooms storytelling. Additionally, stories can be used appropriately as an effective educational tool in developing students' educational values.

\section{Recommendations}

In light of the results, the study suggests:

- Concentrating on national values in the fourth-grade stories collections, due to its role in preparing the individual to be more belonging to his country and more eager to advance it.

- Conducting a study in aim to define fourth and fifth grades teachers' perspectives about the stories' collections provided for them in the Hashemite Kingdom of Jordan.

- Conducting a study aims to reveal the reflections of the educational values in included in the stories' collections provided for fourth and fifth grades in the Hashemite Kingdom of Jordan on student's behaviors.

\section{Appendix 1}

\section{Instrument of the Study}

\begin{tabular}{|c|c|}
\hline $\begin{array}{c}\text { Educational } \\
\text { Values } \\
\text { Domains } \\
\end{array}$ & Indicators \\
\hline $\begin{array}{l}\text { Cognitive } \\
\text { Values }\end{array}$ & $\begin{array}{ll}\text { - } & \text { Developing Thinking } \\
\text { - } & \text { Encouraging problem understanding and } \\
\text { - } & \text { providing scientific solutions } \\
\text { - } & \text { Emphoting curiosity } \\
\end{array}$ \\
\hline Health Values & $\begin{array}{ll}\text { - } & \text { Emphasizing the importance of sport } \\
\text { - } & \text { Encouraging personal hygiene } \\
\text { - } & \text { Preservation of the environment } \\
& \text { Highlight the importance of healthy } \\
\text { nutrition }\end{array}$ \\
\hline Social Values & $\begin{array}{ll}\text { - } & \text { Promoting good habits } \\
\text { - } & \text { Fulfilling responsibilities } \\
\text { - } & \text { Stressing the importance of collaboration } \\
\text { - } & \text { Society } \\
\text { - } & \text { Importance of respecting others } \\
\end{array}$ \\
\hline $\begin{array}{c}\text { Personal } \\
\text { Values }\end{array}$ & $\begin{array}{ll}\text { - } & \text { Time respect } \\
\text { - } & \text { Seriousness } \\
\text { - } & \text { Persistence } \\
\text { - } & \text { Self-Reliance } \\
\text { - } & \text { Accepting others opinion } \\
\text { - } & \text { Discussion } \\
\end{array}$ \\
\hline $\begin{array}{c}\text { National } \\
\text { Values }\end{array}$ & $\begin{array}{l}\text { - } \quad \text { Promote patriotism } \\
\text { Save gardens of homeland properties and } \\
\text { wealth. } \\
\text { - } \quad \text { Providing community service }\end{array}$ \\
\hline
\end{tabular}

\section{REFERENCES}

[1] Al-Anany, H. (2017). Development of social, religious and moral concepts in early childhood. Amman: Dar Al Fikr Publishing.

[2] Al-Baga, E. (2017). Teaching children skills of reading and writing. Amman: Dar Al Fikr Publishing.

[3] Al-Hareary, R. (2015). Introduction for child parenting. Amman: Dar Al Fikr Publishing.

[4] Al-Hashmy, E. \&Atyah, M. (2011). Analyzing the content of school curriculum. Amman: Dar Safa for Printing, Publishing and Distribution. 
[5] Al-Jalad, M. (2013). Learning and teaching values. Amman: Dar Al Massira for Publishing, Printing and Distribution.

[6] Al-Khataybeh, E. (2011). Teaching science for everyone. Amman: Dar Al Massira for Publishing, Printing and Distribution.

[7] Al-Khawaldeh, M. (2011). The foundations of developing educational curricula and designing the educational book. Amman: Dar Al Massira for Publishing, Printing and Distribution.

[8] Al-Mahasneh, O., Ayasrah, M., Yahyaa, S., Al-Kriemeen, R., \& Al-Swalha, A. (2020). Favorite methods of teaching and evaluation among students in university colleges. International Journal of Education and Practice, 8(2), 365-378.

[9] Almseidein, T., \& Mahasneh, O. (2020). Awareness of ethical issues when using an e-learning system. International Journal of Advanced Computer Science and Applications, 11(1), 128-131.

[10] Al-Nashef, H. (2017). Family and child parenting. Amman: Dar Al Massira for Publishing, Printing and Distribution.

[11] Al-Yamany, E. (2015). Education philosophy. Amman: Dar Alshorok for Publishing and Distribution.

[12] Al-Zboun, H. \& Al-Daqas, N. (2009). The status of My Arabic Library project in Ministry of Education schools in Jordan from point of view of school principal, teacher, student and parent. Unpublished Research, Jordanian Ministry of Education, Jordan.

[13] Al-Zreqat, I. \& Naser, S. (2005). Introduction in early childhood education from pre-school to the early grades. Amman: Dar Al Fikr Publishing.

[14] Butrous, B. (2017). Instruct ordinary children. Amman: Dar Al Massira for Publishing, Printing and Distribution.

[15] Chua, S. (2017). Storytelling in the social studies classroom. Research and Practice in Humanities \& Social Studies Education, 6(2), 79-87.

[16] Combariza, C., Chapetón, M. \& Rincón, V. (2013). Social values reflections through the use of EFL storytelling: An action research with primary students. HOW Journal a Colombian Journal for Teachers of English, 20(10), 73-89

[17] Ebwany, E. (2008). Educational content of the Jordanian children's magazines: Content analysis of Wesam and Hatem Magazines. Unpublished PhD Dissertation, Yarmouk University, Jordan.

[18] Ellis, G. \& Brewster, J. (1991). The storytelling handbook for primary teachers. London, UK: Penguin Books.

[19] Gulati, S. \& Pant, D. (2020). Education for values in schools: A framework. Department of Educational Psychology and Foundations of Education. National Council of Educational Research and Training. Sri Aurobindo Marg, New Delhi. Retrieved fromhttp://www.ncert.nic.in/departments/nie/dep fe/Final.pdf.

[20] Hill, Brian V. (2000). in Leicester, M., Modgil, C. and Modgil, S. (eds) Education, Culture and Values: II. Institutional Issues: Pupils, Schools and Teacher Education. London and New York: Falmer Press, 198207. Hutchinson,
Frank and Waddell, Lyn.

[21] Hussein, A. (2011). Educational values in the stories of My Arab Library project and their ramifications on the children's behavior. Unpublished $\mathrm{PhD}$ Dissertation, Yarmouk University, Jordan.

[22] IbnKhaldun, E. (2007). Muqaddimah Ibn Khaldun. Amman: Dar Al Fikr Publishing.

[23] Ibrahim, M. \& Hafed, O. (2017). Child culture. Amman: Dar Al Fikr Publishing.

[24] Isbell, R., Sobol, J. \& Lindauer, L. (2004). The effects of storytelling and story reading on the oral language complexity and story comprehension of young children. Early Childhood Education Journal, 32, 157-163.

[25] KaramAldean, L. (2002). Educational values in children's magazines. Kuwait: Arab Child Book/Al-Arabiya Journal.

[26] Mahasneh, O. (2020a). A proposed model for the university students' e-portfolio. Journal of Education and e-Learning Research 7(1), P28-34.

[27] Mahasneh, O. (2020b). The effect of teaching by (mobile learning) in university students' achievement. Proceedings of the 16th International Conference Mobile Learning 2020, Bulgaria, IADIS.DOI: 10.33965/ml2020_202004C017.

[28] Mahasneh, O.(2020c). Dataset on perception among male secondary school students on underage smoking in Jordan. Proceedings of the 16th International Conference Mobile Learning 2020, Data in Brief, 29, P1-8.

[29] Mahmoud, K. (2009). An evaluation study of implementation of "My Arabic Library" project in elementary stage: (Developmental model). Unpublished PhD Dissertation, Jordanian University, Jordan.

[30] Ministry of Education. (2013). Set of educational rules, regulations and instructions. Amman: Department of Legal Affairs, Legal Legislation Department.

[31] Qatamy, Y. (2016). Cognitive learning and teaching strategies. Amman: Dar Al Massira for Publishing, Printing and Distribution.

[32] Rahim, H. \& Rahiem, M. (2012). The use of stories as moral education for young children. International Journal of Social and Humanity, 2(6), 454-458.

[33] Scholastic. (2006). My Arabic Library: Teacher guide for the first and second years, (1st Ed.). New York, USA.

[34] Shrief, S. (2017). Social and religious education in kindergarten. Amman: Dar Al Massira for Publishing, Printing and Distribution.

[35] Sim, H. (2004). Storytelling for social studies in the primary classroom. Teaching and Learning, 25(2), 139-148.

[36] Souada, J. \& Ibrahim, A. (2011). Contemporary school curriculum. Amman: Dar Al Fikr Publishing.

[37] Tan, C. (2008). Two views of education: Promoting civic and moral values in Cambodia schools. International Journal of Education Development, 28(5), 560-570.

[38] Tawarah, H. \& Mahasneh, O. (2020). The Reality of University Education in Jordan from the Viewpoint of 
